\title{
Impact of Urinary Arsenic Level on Simple Diffuse Goiter
}

\author{
Md. Sharif Hossain ${ }^{1}$ and Fatema Begum ${ }^{2}$ \\ ${ }^{1}$ Department of Economics, College of Social Sciences, Kazakhstan Institute of \\ Management, Economics, and Strategic Research, Republic of Kazakhstan \\ ${ }^{2}$ Institute of Nuclear Medicine and Ultrasound, Bangabandhu Sheikh Mujib Medical University, Dhaka, \\ Bangladesh
}

\begin{abstract}
The impacts of urinary arsenic level on simple diffuse goiter was studied in Bangladeshi population. A correlation of urinary iodine, radioiodine uptake, thyroid stimulating hormone (THS) and free thyroxin ( $\mathrm{FT}_{4}$ ) levels was made on urinary arsenic level using a case-control analytical study. Out of 85 subjects 45 were considered for experimental group with simple diffuse goiter and rest 40 were considered for healthy control group without any thyroid disease. From the experimental results it has been found that iodine deficiency is not only the factor of causing simple diffuse goiter, but arsenic level is also one of the most important factors of causing simple diffuse goiter. It has also been found that the radioiodine uptake levels at 2 hours and 24 hours and the serum $\mathrm{FT}_{4}$ have negative impacts on arsenic levels for both the experimental and control group. Their impacts are not statistically significant except the variable radioiodine uptake levels at 24 hours. The serum TSH has positive impact on arsenic level for both experimental and control groups but not statistically significant. The estimated results revealed that the variable radioiodine uptake level at 24 hours play the significant role for reducing arsenic level.
\end{abstract}

Key words: Urinary Arsenic, Iodine Deficiency, Simple Diffuse Goiter, Urinary iodine, Thyroid Stimulating Hormone, Free Thyroxin and Radioiodine Uptake Level

\section{INTRODUCTION}

Thyroid disorder is one of the major health hazards in many countries including Bangladesh. ${ }^{1}$ Bangladesh is situated in the zone of iodine deficiency area in the belt of the Brahmaputra River, so goiter and iodine deficiency are very common in this part of the counry. ${ }^{2}$ Goiter may be classified into many ways. It may be toxic or nontoxic according to patients' toxic status, diffuse or nodular according to its consistency, endemic and sporadic epidemiology.

Correspondence to: Md. Sharif Hossain

E-mail : hossain@kimep.kz

Dhaka Univ. J. Pharm. Sci. 7(2): 161-168, 2008 (December)
Simple diffuse goiter (SDG) usually presents between the ages of 15-25 years. Female and adolescents are usually sufferer and more often during pregnancy. Simple diffuse goiter is also termed as endemic goiter as it usually occurs in large numbers of certain population. The great arc of the Himalayas from Pakistan across India, Nepal, Northern Thailand, Vietnam and Indonesia are one of the most highly endemic regions of the world. ${ }^{3}$ Regarding the word endemic, this has been defined as a prevalence rate of more than $10 \% .{ }^{4,5}$ There is now a tendency to decrease this figure from $10 \%$ to $5 \%$. Therefore, more arena will be classified as having a problem of endemic goiter. ${ }^{6}$ According to 1999 national survey in 80 places in Bangladesh, 
conducted on children of 5-11 years and adults of 1544 years of 20978 subjects, total goiter rate (TGR) was $17.8 \% .^{7}$ In 1993 national survey nearly half (47\%) of the population had symptoms of goiter. ${ }^{7}$ Total goiter rate (TGR) is declining due to availability of iodized salt in the market.

According to Stanbury et al. ${ }^{8}$ the main cause of endemic goiter is the iodine deficiency. ${ }^{6}$ Other causes are genetic, iodine excess, goitrogens and some drugs like PAS, thiocyanate and so on. ${ }^{9}$ Poverty is also another factor of causing of endemic goiter. The arguments supporting iodine deficiency as the cause of endemic goiter. Several other goitrogens have been described in various plants as well as in the drinking water. ${ }^{6}$ Iodine in large concentration is itself a goitrogen. "Iodide goiter" has been described in Japan in a coastal area where the inhabitants consumed large quantities of sea-plants with high iodine content ${ }^{10}$ and recently in China due to a high iodine concentration in the drinking water. ${ }^{11}$

Arsenic is a metalloid widely distributed in the earth's crust. It can exist in four different states, -3 , $0,+3$, and +5 . In strongly reducing environments, elemental arsenic and arsine (-3) can exist. Under moderately reducing conditions, arsenite $(+3)$ may be the dominant form, but arsenate $(+5)$ is generally the stable oxidation state in oxygenated environments. Arsenic is mainly transported in the environment through water. Methylation of inorganic arsenic to methyl and di-methyl arsenic acids is associated with biological activity in water. Some marine organisms have been shown to transform inorganic arsenic into more complex organic compounds, such as Arsenobetaine, Arsenocholine and Arsonium phospholipids. ${ }^{12}$ The arsenic concentration in human organs and tissues (in $\mathrm{mg} / \mathrm{kg}$ ) are as, adrenal (0.03), aorta (0.04), whole blood (0.04), brain (0.01), hair (0.46), heart (0.02), kidney (0.03), liver (0.03), lung (0.08), muscle (0.06), nail $(0.28)$, ovary $(0.05)$, pancreas $(0.05)$, prostate $(0.04)$, skin (0.08), spleen (0.02), stomach (0.05), teeth $(0.05)$, tyymus (0.02), thyroid (0.04) and uterues $(0.04){ }^{13}$
In Bangladesh drinking water is heavily contaminated with arsenic. Arsenic is an important environmental contaminant being number one in the EPA (environmental protection agency) superfund list. An estimated 50 million people are at risk from drinking arsenic contaminated water in Bangladesh and West Bengal, India. ${ }^{13}$ A large number of populations in many districts of Bangladesh are drinking ground water with arsenic concentrations for above acceptable levels $(0.05 \mathrm{mg} / \mathrm{l})$ and many of them have already been diagnosed with poisoning symptoms, even though much of the at-risk population has not yet been assessed for arsenic related health problems. So, there might be a correlation of body arsenic status with goiter. Arsenic is a direct antagonist of selenium and uses up selenium in the process of detoxifying arsenic. On the other hand selenium is critical for converting thyroxin $\left(\mathrm{T}_{4}\right)$ to triodothyronin $\left(\mathrm{T}_{3}\right)$. So arsenic can contribute to hypothyroidism by using up selenium. ${ }^{14}$ The study deals with the impact of urinary arsenic level on simple diffuse goiters and body arsenic status in Bangladeshi population. Simultaneously this research is conducted to find the impacts of urinary iodine level, THS and $\mathrm{FT}_{4}$ level and radioiodine uptake level on urinary arsenic level.

In this study urinary arsenic concentration of patients of simple diffuse goiter are considered for measurement to assess the body arsenic status.

Urinary arsenic is considered for measurement because arsenic in urine, hair and nail has been used as the most reliable indicator for monitoring the exposure of victim to arsenic. ${ }^{15}$

\section{MATERIALS AND METHODS}

The study was carried out in the Institute of Nuclear Medicine and Ultrasound, in collaboration with the out patient department of Bangabandhu Sheikh Mujib Medical University (BSMMU), Dhaka Bangladesh. A total of eighty five (85) patients were considered in the study. Among them forty five (45) patients were considered for experimental group with simple diffuse goiter after diagnosis and rest forty 
(40) patients were considered for control group without any obvious thyroid disorder, all of them are apparently healthy. Among the experimental group thirty eight (38) were female and seven (7) were male; and in control group twenty nine (29) were female and eleven (11) were male respectively. The age of all the patients group were between 5 to 25 years. In the experiment patients having nodular goiter, thyroid dysfunction, pregnancy, lactation and those who are taking drugs like steroid, lithium, iodine containing drugs were excluded from the study.

Study Procedure. Relevant information were recorded on a questionnaire from all patients. After taking the history each patient underwent careful physical and thyroid examination. All these findings are recorded in a data sheet. Five milliliter venous blood was collected from each subject with all aseptic preparation in clean and dry test tubes for the measurement of serum thyroid stimulating hormone (TSH), serum free thyroxin $\left(\mathrm{FT}_{4}\right)$, thyroid autoantibodies, antithyroperoxidase antibody (Anti TPO Ab), antithyroglbulin antibody (Anti $\mathrm{Tg} \mathrm{Ab}$ ). Urine samples were collected in clean dry and metal free containers for the determination of urinary iodine and urinary arsenic levels. The samples were store at $4^{\circ} \mathrm{C}$ temperature for later estimation.

Estimation of serum TSH and $\mathbf{F T}_{\mathbf{4}}$. Serum human TSH and $\mathrm{FT}_{4}$ measurement was based on RIA and IRMA. Estimation of serum Anti TPO and Anti Tg Ab measurement was based on microparticle enzyme immunoassay (MEIA) principle. ${ }^{16}$

Urinary iodine determination. Urinary iodine was measured by Method-B. ${ }^{17}$ Urine is digested with chloric acid solution. Iodide is the catalyst in the reduction of ceric ammonium sulfate (yellow) to cerous form (colorless), and is detected by rate of color disappearance.$^{18}$

Urinary arsenic determination. Urine samples were diluted with matrix modifier using a standard protocol. The determination of total content of arsenic in urine was done by graphite furnace atomic absorption spectrometry (GFAAS) systems. $^{19}$
Calibration curve was used before each cycle of measurement using standard supplied by Waco Inc.

\section{RESULTS AND DISCUSSION}

The variable urinary iodine, urinary arsenic, TSH, $\mathrm{FT}_{4}$ and radioiodine uptake with simple diffuse goiter and normal patients were evaluated in a case-control study. In the study it was found that maximum patients for experimental group lie at the age group 15-20 years, but for control the maximum patients lie at the age group 20-25 years Figure 1.

The urinary arsenic and iodine levels for both the experimental and control groups were observed (Table 1). It has been found that for the experimental group $6.67 \%$ patients contain below normal, $40 \%$ patients contain normal and $53.33 \%$ patients contain above normal level of arsenic and there is no patient below normal, $92.5 \%$ patients fall within normal and $7.5 \%$ patients fall above normal level of arsenic for the control group. This indicates that there are significant differences between experimental and control groups in terms of arsenic levels. The $\chi^{2}$-test result revealed that the experimental and control groups are not homogeneous in respect of arsenic levels. Similarly it was observed that $6.67 \%$ patients were moderately iodine deficiency, $4.44 \%$ patients were mild iodine deficiency, $6.67 \%$ optimal $8,89 \%$ more than adequate and $73.33 \%$ excessive urinary iodine in experimental group. But the control group exhibited $7.5 \%$ more than adequate and $92.5 \%$ escessive urinary iodine. None of the experimental and control groups exhibited serve urinary iodine deficiency. The chi-square test result showed that the two samples of experimental and control groups are homogeneous in terms of urinary iodine level, which indicates that iodine is not only the factor of causing simple diffuse goiters, but arsenic is also an another important factor. Thus it can be concluded that, arsenic level plays significant role of causing simple diffuse goiter in Bangladesh population.

The median values, range, the Mann Whitney Utest results with their lower and upper limits, and the standard normal test results with the p-values for 
urinary arsenic levels, and urinary iodine levels, for both experimental and control groups are reported in the Table 2. From the Mann-Whitney U-test results or results of the standard normal test, it can be concluded that the arsenic levels between experimental and control groups are significantly different but the urinary iodine levels between experimental and control groups are not statistically different. Thus we can say that two samples i.e. experimental and control groups are same in terms of iodine levels but they are heterogeneous in terms of arsenic levels. Thus from the Mann-Whitney U-test results it can be concluded that in Bangladesh iodine level is not only the factor of causing simple diffuse goiter but arsenic level is also another important factor of causing simple diffuse goiter.

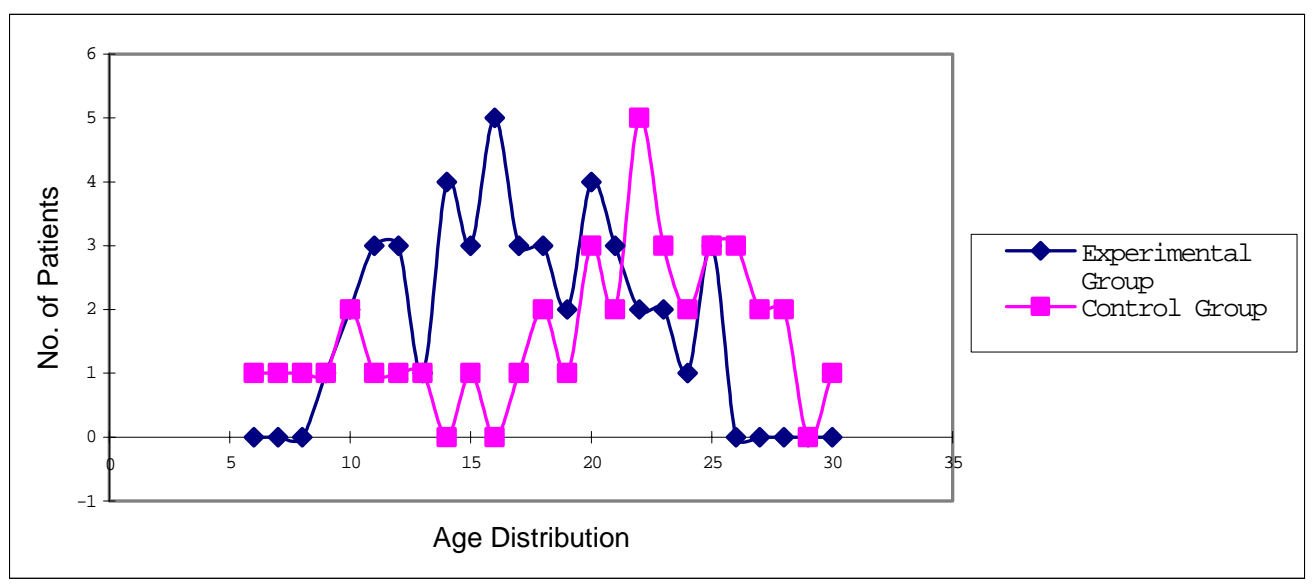

Figure 1. Age distribution with the no. of patients for experimental and control groups

Table 1. Urinary Arsenic and Iodine Groups with the No. Patients and the $\chi^{2}$-test for Homogeneity with the p-Value

\begin{tabular}{|c|c|c|c|c|c|c|c|c|}
\hline \multirow[t]{2}{*}{ Sample } & \multicolumn{7}{|c|}{ Urinary Arsenic Groups, Normal Range is (05ppb - 50ppb) } & \multirow{2}{*}{$\begin{array}{l}\chi^{2} \text {-test for } \\
\text { Homogeneity }\end{array}$} \\
\hline & \multicolumn{2}{|l|}{ No. of Patients } & Below Normal & \multicolumn{2}{|c|}{ Within Normal } & \multicolumn{2}{|c|}{ Above Normal } & \\
\hline Experimental & \multicolumn{2}{|l|}{ No. of Patients } & \multirow{2}{*}{3} & \multicolumn{2}{|c|}{18} & \multicolumn{2}{|c|}{24} & \multirow{4}{*}{$\begin{array}{l}25.691751 \\
(0.00000264)\end{array}$} \\
\hline Group & \multicolumn{2}{|c|}{ No. of patients in $\%$} & & \multicolumn{2}{|c|}{$40 \%$} & \multicolumn{2}{|c|}{$53.33 \%$} & \\
\hline Control & \multirow{2}{*}{\multicolumn{2}{|c|}{$\begin{array}{l}\text { No. of Patients } \\
\text { No. of patients in \% }\end{array}$}} & 0 & \multirow{2}{*}{\multicolumn{2}{|c|}{$\begin{array}{c}37 \\
92.5 \%\end{array}$}} & \multirow{2}{*}{\multicolumn{2}{|c|}{$\begin{array}{c}3 \\
7.5 \%\end{array}$}} & \\
\hline \multirow[t]{3}{*}{ Group } & & & 0 & & & & & \\
\hline & \multicolumn{7}{|c|}{ Urinary Iodine Groups } & $\begin{array}{l}\chi^{2} \text {-test for } \\
\text { Homogeneity }\end{array}$ \\
\hline & $\begin{array}{l}\text { No. of } \\
\text { patients }\end{array}$ & $\begin{array}{c}\text { Severe } \\
\text { iodine } \\
\text { deficiency }\end{array}$ & $\begin{array}{l}\text { Moderate } \\
\text { iodine } \\
\text { deficiency }\end{array}$ & $\begin{array}{c}\text { Mild } \\
\text { iodine } \\
\text { deficiency }\end{array}$ & Optimal & $\begin{array}{c}\text { More } \\
\text { than } \\
\text { adequate }\end{array}$ & Excessive & \\
\hline \multirow[t]{2}{*}{$\begin{array}{l}\text { Experimental } \\
\text { Group }\end{array}$} & $\begin{array}{l}\text { No. of } \\
\text { patients }\end{array}$ & 0 & 3 & 2 & 3 & 4 & 33 & \\
\hline & $\begin{array}{l}\text { No. of } \\
\text { Patients } \\
\text { in } \%\end{array}$ & $0 \%$ & $6.67 \%$ & $4.44 \%$ & $6.67 \%$ & $8.89 \%$ & $73.33 \%$ & $\begin{array}{l}8.105357 \\
(0.150523)\end{array}$ \\
\hline \multirow[t]{2}{*}{ Control Group } & $\begin{array}{l}\text { No. of } \\
\text { patients }\end{array}$ & 0 & 0 & 0 & 0 & 3 & 37 & \\
\hline & $\begin{array}{l}\text { No. of } \\
\text { Patients in \% }\end{array}$ & $0 \%$ & $0 \%$ & $0 \%$ & 0 & $7.5 \%$ & $92.5 \%$ & \\
\hline
\end{tabular}

Note : The numbers in the parentheses are the p-values of the $\chi^{2}$-test

From the estimated results, it has been found that urinary iodine is positively associated with urinary arsenic and TSH levels and negatively associated with $\mathrm{FT}_{4}$ and radioiodine uptake levels at 2 hours and 24 hours for experimental group using Spearman"s rank correlation coefficient (Table 3). From t-test results it has been found that only the association between iodine level and radioiodine uptake level at 2 hours is statistically significant. Also, it has been found that urinary arsenic is positively related with 
TSH level and negatively related with $\mathrm{FT}_{4}$ and radioiodine uptake levels. But these associations are not statistically significant. Thus it can be said, if TSH level is increased, the arsenic level will also be increased, if $\mathrm{FT}_{4}$ and radioiodine uptake levels are increased the arsenic level will be decreased.

From the estimated results of Spearman's rank correlation coefficient between different pairs of variables for control group it has been found that urinary iodine is positively associated with urinary arsenic, $\mathrm{FT}_{4}$ level and radioiodine uptake level at 24 hours and negatively associated with TSH and radioiodine uptake level at 2 hours. Only the association between iodine level and TSH level is statistically significant. Also, it has been found that urinary arsenic is positively related with $\mathrm{FT}_{4}$ level and negatively associated with TSH and radioiodine uptake level. But these associations are not statistically significant. Thus from the estimated results it can be concluded that if TSH and radioiodine uptake levels are increased arsenic level will be decreased and if $\mathrm{FT}_{4}$ level is increased the arsenic level will be increased.

Table 2. Mann-Whitney U-Test for Comparison of Urinary Arsenic, and Urinary Iodine Levels, Between Experimental and Control Groups

\begin{tabular}{|c|c|c|c|c|c|c|}
\hline & Median & Range & $\begin{array}{l}\text { U-Test } \\
\text { Value }\end{array}$ & $\mathrm{E}(\mathrm{U})$ & $\begin{array}{l}\text { Lower and Upper } \\
\text { Critical Values of U }\end{array}$ & $\begin{array}{l}\text { Standard Normal Test } \\
\text { (p-value) }\end{array}$ \\
\hline Study Subjects & \multicolumn{6}{|c|}{ Urine Arsenic Level (ppb) } \\
\hline $\begin{array}{l}\text { Experimental } \\
\text { Group }(n=45) \\
\text { Control Group }(n=40)\end{array}$ & $\begin{array}{l}85.35 \\
36.0\end{array}$ & $\begin{array}{c}1.50-275.8 \\
18-70\end{array}$ & 1236 & 900 & $\begin{array}{l}\text { Lower Limit (677.39) } \\
\text { Upper Limit (1122.61) }\end{array}$ & $\begin{array}{c}2.9583 \\
(0.003093)\end{array}$ \\
\hline Study Subjects & \multicolumn{6}{|c|}{ Urinary Iodine Concentration Level $(\mu \mathrm{g} / \mathrm{l})$} \\
\hline $\begin{array}{l}\text { Experimental } \\
\text { Group }(\mathrm{n}=45) \\
\text { Control Group }(\mathrm{n}=40)\end{array}$ & $\begin{array}{l}443.70 \\
413\end{array}$ & $\begin{array}{l}45.05-480.4 \\
240-474\end{array}$ & 1021.5 & 900 & $\begin{array}{l}\text { Lower (677.39) } \\
\text { Upper(1122.61) }\end{array}$ & $\begin{array}{c}1.069749 \\
(0.28473211)\end{array}$ \\
\hline
\end{tabular}

Note : The numbers in the parentheses are the p-values of the Standard Normal-test

Table 3. Spearman's Rank Correlation Coefficients with the t-Test Values Between Different Pairs of Variables for Experimental Group

\begin{tabular}{lcc}
\hline \multicolumn{1}{c}{ Correlation Between Different Pairs of Variables } & $\begin{array}{c}\text { Spearman's Rank } \\
\text { Correlation }(\hat{\rho})\end{array}$ & $\begin{array}{c}\text { t-Test Statistic } \\
(\mathrm{p} \text {-value })\end{array}$ \\
\hline Correlation Between Urinary Iodine and Urine Arsenic & 0.1676 & 1.114720 \\
& & $(0.27116228)$ \\
& 0.8574 \\
Correlation Between Urinary Iodine and TSH & 0.1296 & $(0.39599387)$ \\
Correlation Between Urinary Iodine and FT & -0.704045 \\
Correlation Between Urinary Iodine and RAIU at 2 Hours & -0.1068 & $(0.48520032)$ \\
Correlation Between Urinary Iodine and RAIU at 24 Hours & -2.59916 \\
Correlation Between Urinary Arsenic and TSH & -0.3685 & $(0.01275292)$ \\
Correlation Between Urinary Arsenic and FT & -0.3582 \\
Correlation Between Urinary Arsenic and RAIU at 2 Hours & -0.0545 & $(0.72193747)$ \\
Correlation Between Urinary Arsenic and RAIU at 24 Hours & 0.1738 & 1.157172 \\
& -0.1105 & -0.7289 \\
& -0.0149 & $(0.47002043)$ \\
-0.097422 \\
\end{tabular}

In order to find the impacts of urinary iodine, radioiodine uptake, thyroid stimulating hormone (THS) and free thyroxin $\left(\mathrm{FT}_{4}\right)$ level on urinary arsenic level, here we applied the regression equation. The regression equstion of urinary arsenic level on these variables is given by;

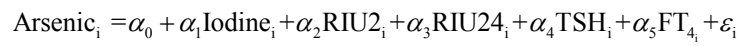
$(\mathrm{i}=1,2, \ldots . ., \mathrm{n})$ 
Here,

Arsenic indicates arsenic level, Iodine indicates iodine level, RIU2 indicates radioiodine uptake level at 2 hours, RIU24 indicates radioiodine uptake level at 24 hours, TSH indicates serum thyroid stimulating hormone, $\mathrm{FT}_{4}$ serum free thyroxin, and $\varepsilon$ indicates random error term, the subscript $i$ is used for the number of observations for each group. The estimated results for both experimental and control groups are given below;

Table 4. Spearman's Rank Correlation Coefficients with the t-Test Values Between Different Pairs of Variables for Control Group

\begin{tabular}{|c|c|c|}
\hline Correlation Between Different Pairs of Variables & $\begin{array}{l}\text { Spearman's Rank } \\
\text { Correlation }(\hat{\rho})\end{array}$ & $\begin{array}{l}\text { t-Test Statistic } \\
\text { (p-value) }\end{array}$ \\
\hline Correlation Between Urinary Iodine and Urine Arsenic & 0.1361 & $\begin{array}{c}0.846960 \\
(0.40232008)\end{array}$ \\
\hline Correlation Between Urinary Iodine and TSH & -0.7000 & $\begin{array}{l}-6.043128 \\
(0.000000)\end{array}$ \\
\hline Correlation Between Urinary Iodine and FT4 & 0.1457 & $\begin{array}{c}0.907746 \\
(0.36973333)\end{array}$ \\
\hline Correlation Between Urinary Iodine and RAIU at 2 Hours & -0.0663 & $\begin{array}{c}-0.409743 \\
(0.68429541)\end{array}$ \\
\hline Correlation Between Urinary Iodine and RAIU at 24 Hours & 0.0945 & $\begin{array}{c}0.584939 \\
0.56204622\end{array}$ \\
\hline Correlation Between Urinary Arsenic and TSH & -0.0273 & $\begin{array}{c}-0.168051 \\
(0.86743411)\end{array}$ \\
\hline Correlation Between Urinary Arsenic and FT4 & 0.0488 & $\begin{array}{c}(0.301062) \\
(0.76500882)\end{array}$ \\
\hline Correlation Between Urinary Arsenic and RAIU at 2 Hours & -0.1163 & $\begin{array}{c}-0.721962 \\
(0.47473710)\end{array}$ \\
\hline Correlation Between Urinary Arsenic and RAIU at 24 Hours & -0.2763 & $\begin{array}{c}-1.772310 \\
(0.08436095)\end{array}$ \\
\hline
\end{tabular}

Table 5. Parameter Estimates of the Regression Equation for both Experimental and Control Groups

\begin{tabular}{|c|c|c|c|c|c|}
\hline \multirow[t]{2}{*}{ Parameters } & \multicolumn{5}{|c|}{ Regression Results for Experimental Group } \\
\hline & Parameters Value & Standard Error & t-test & p-value & $\overline{\mathbf{R}^{2}}$ \\
\hline$\alpha_{0}$ & 169.9883026 & 64.0918155 & 2.65226 & 0.01150166 & \multirow{6}{*}{$67.9714 \%$} \\
\hline$\alpha_{1}$ & -0.0219976 & 0.0696214 & -0.31596 & 0.75371771 & \\
\hline$\alpha_{2}$ & -1.9973025 & 6.2882471 & -0.31762 & 0.75246404 & \\
\hline$\alpha_{3}$ & -4.3805897 & 1.9281385 & -2.27193 & 0.02868515 & \\
\hline$\alpha_{4}$ & 6.9287725 & 8.3628173 & 0.82852 & 0.41241721 & \\
\hline$\alpha_{5}$ & -2.8751893 & 4.2276390 & -0.68009 & 0.50046280 & \\
\hline & \multicolumn{5}{|c|}{ Regression Results for Control Group } \\
\hline Parameters & Parameters Value & Standard Error & t-test & $p$-value & $\mathbf{R}^{2}$ \\
\hline$\alpha_{0}$ & 35.70168394 & 27.47363003 & 1.29949 & 0.20251861 & \multirow{6}{*}{$92.8855 \%$} \\
\hline$\alpha_{1}$ & 0.04587977 & 0.05296514 & 0.86623 & 0.39243813 & \\
\hline$\alpha_{2}$ & -0.12841871 & 1.60331266 & -0.08010 & 0.93663062 & \\
\hline$\alpha_{3}$ & -1.38404344 & 0.87672563 & -1.57865 & 0.12367608 & \\
\hline$\alpha_{4}$ & 0.59147085 & 2.62667154 & 0.22518 & 0.82318813 & \\
\hline$\alpha_{5}$ & -0.03539730 & 1.28690939 & -0.02751 & 0.97821723 & \\
\hline
\end{tabular}

In order to measure the impacts of the variables urinary iodine, radioiodine uptake, thyroid stimulating hormone (THS) and free thyroxin $\left(\mathrm{FT}_{4}\right)$ level on urinary arsenic levels for both experimental and control groups, the estimated values are reported in Table (5). From the estimated result of parameter $\alpha_{1}$ in Table (5), it has been found that the variable iodine has negative impact on arsenic level for experimental group, but for the control group it has positive impact. From the t-test results it has been found that the impacts are not statistically significant. Also from the estimated results of the parameters $\alpha_{2}, \alpha_{3}$ and $\alpha_{5}$, it has been found that the variables radioiodine uptake at 2 hours and 24 hours and serum $\mathrm{FT}_{4}$ have negative impacts on arsenic levels for both the experimental and control group. From the tstatistic it can be concluded these impacts are not statistically significant except the variable radioiodine uptake level at 24 hours. The impact of radioiodine uptake level at 24 fours is statistically 
significant for the experimental group but for the control group it is not statistically significant. The serum TSH has positive impact on arsenic level for both experiment and control groups but not statistically significant. Thus from the estimated regression equation, it can be concluded that the variable radioiodine uptake level at 24 hours plays the significant role for reducing the arsenic level.

\section{CONCLUSION}

There are some postulated mechanisms of arsenic affecting the thyroid gland. One of those is arsenic reduces the uptake of iodine in thyroid gland. According to $^{20}$, diabetes mellitus and goiter have been reported in association with prolonged ingestion of arsenic through drinking water. It was found that high level of arsenic led to iodine deficiency ${ }^{21}$ also in this study same conclusion can be drawn from regression analysis. Another postulation is that arsenic is a direct antagonist of selenium which is used up in the process of detoxifying arsenic, and selenium is critical for converting $\mathrm{T}_{4}$ to $\mathrm{T}_{3}$. By this process arsenic may led to hypothyroidism. ${ }^{13}$ The prevalence of goiter in school children and females from the arsenic endemic area was higher than that from the non endemic area. ${ }^{22}$ Median urinary arsenic level of simple diffuse goiter patients was $85.35 \mathrm{ppb}$ and $36 \mathrm{ppb}$ in control. Control had level below the recommended value of $50 \mathrm{ppb}$ for Bangladesh ${ }^{15}$, whereas the urinary arsenic level in simple diffuse goiter patients was far above the recommended level. From this research finally it has been concluded that iodine deficiency is not only the factor of causing goiter but arsenic is also another important factor of causing goiter in Bangladesh population, that is why the goiter rate in school children and females from the arsenic endemic area was higher than that from the non endemic area.. Also, it has been found that the radioiodine uptake at 24 hours plays the significant role of reducing the arsenic level but not serum TSH level .

\section{REFERENCES}

1. Ansari, S.M., and Ajoedi, D.Y. 1995. Thyroid disorder pattern. J. DAB, Dhaka, Bangladesh, 23, 5-8.

2. Yusuf, H.K.M., Quazi, S., and Pandav, C.S. 1993. Report of national iodine deficiency disorder survey in Bangladesh. UNICEF / ICCIDD, Dhaka University.

3. Delange, R.F., and Hetzel, B. 2004. Iodine deficiency disorder [Online], in the thyroid and its diseases, Endocrine education, Available from:http://www.thyroidmanager.org/chapter20/20 frame.htm [10/03/2004].

4. Koutras, D.A. 1971. Non-toxic goiter: endemic. In: The Thyroid. A Fundamental and Clinical Text. 3d ed., eds SC Werner and SH Ingbar, Harper and Row, New YorkEvanston-San Francisco-London 11, 409-423.

5. Querido, A., Delange, J., Dunn, T., Fierro-Benitez, R., Ibbertson, H.K., Koutras, D.A., and Perinetti, H. 1974 Definition of endemic goiter and retinism classification of goiter size and severity of endemics and survey techniques" WHO publications No. 29, Washington DC, USA, pp. 267272.

6. Koutras, D.A. 2002. Endemic Goiter an Update. Hormones 1(3), 157-164.

7. Pandav S.C. ICCIDD. 2004. Report of the regional coordinator, South Asia Region.

8. Stanbury, J.B., Brownell, G.L., Riggs, D.S., Perinetti, H., DelCastillo, E.B., and Itoiz, J. 1954. Endemic goiter. The adaptation of man to iodine deficiency. Harvard University Press. Cambridge, Mass, USA.

9. Grayson R.R. 1960. Factors which influence the radioactive iodine thyroidal uptake teat. Amer. J. Med. 28, 397-415.

10. Suzuki, H., Higushi, T., Sawa, K., Khtaki, S., and Koniuchi, Y. 1965. Endemic coast goiter in Hokkaido: Japan. Acta Endocrinol. 87, 1020-1022.

11. Zhao, J., Wang, P., Shang, L., Sullivan, K.M., Vander H.F., and Maberly, G. 2000. Endemic goiter associated with high iodine intake. Am. J. Public Health 90, 1633-1635.

12. Malachowski, M.E. 1990. An update on arsenic, Clin Lab Med. 10, 459-472

13. WHO. 1981. Environmental Health Criteria 18: Arsenic, International Programme on chemical Safety. IPCS World Health Organization.

14. Mercola. 2004. Arsenic. National Academy of Sciences 2001.

15. Zimmermann, M.B., Molinari, L., Spechl, M., WidningerToth, J., Podoba, J., Hess, S., and Delange, F. 2001. WHOICCIDD reference values for sonographic thyroid volume in iodine-replete school-age children. IDD Newsletter 17, 12. 
16. Newman, D.J. and Price, C.P. 1997. Principles and practice of immunoassay, 2nd ed. London: Macmillan, pp. 443-480.

17. WHO. and N.R., Colledge 1999. Churchil Livingstone, New York, pp. 689-703.

18. Sandell, E. and Kolthoff, I. 1937. Micro determination of iodine by a catalythic method. Microchem Acta 9-25.

19. Shimadzu, 2000. http://www.shimadzu.com.ph/about_us.htm.

20. Dhaka Community Hospital 2001. Arsenic toxicity in human body, [Online], DCH, Available from: http://www.bangladesh.net/article_bangladesh/health/hit_08_ arsenic_toxicity_in_human_body.htm.
21. Yanchev, I., Petrova, N. and Angelov, A. 2001. Some aspects of arsenic pollution influence on sheep milk composition from Chiprovtzi region. Zhivotnov DniNauki, 38, 193-195.

22. Chang, T.C., Hong, M.C. and Chen, C.J. 1991. Higher prevalence of goiter in endemic area of Blackfoot Disease of Taiwan. J. Formosa Med. Assoc. 90, 941-946. 